\title{
The Blue House(s)
}

\author{
Matthew Campbell
}

Research Coordinator

Tangentyere Council

matthew.campbell@tangentyere.org.au

Keywords: Objects of governance, Aboriginal, multiplicity, aboriginal housing, Kathryn Pyne Addelson

I am the research coordinator at Tangentyere Research Hub, part of Tangentyere Council, Alice Springs. In this paper I am trying to think my way through how we might do some more research work on governance and Aboriginal housing, and in particular on the workings of the Housing Reference Groups that have been set up as part of a radical change in the provision of housing services to Aboriginal communities. Since the land rights movement of the 1970s housing for Aboriginal communities has been a matter for the local Housing Association, provided under a communitarian vision of government as local and intimate - a matter of kinship and belonging to place. All that changed very suddenly under the shift towards "normalisation" which started with a military led intervention into Aboriginal communities in the early years of the 21st century (NT National Emergency Response, 2007) when housing in these communities went from being managed by Aboriginal Housing Associations to being managed by the Northern Territory Government as public housing.

In Alice Springs housing is still one of the very big issues for people living on the Town Camps. Because our job as researchers at the Research Hub is to 'make a difference', so we need to keep exploring how we might do productive research in this important area. My concern here is to think about what is going on in the area of housing management, and to do this, I will use what is called in this paper the "Blue House" (others know it more formally as "number 5, Bilson Street"). The Blue House that I use in this paper to explore governance is what many (but not everyone) may think of (unambiguously) as an object. I want to reflect on how the various "players", other participants in what the philosopher Kathryn Pyne Addelson (2002) would call the "ensemble cast" of housing in an Alice Springs Town Camp, are variously positioned by the house as an active socio-political object or entity (Addelson, 2002, pp.118-136), thus contesting the idea that it is an unambiguous, and therefore stable object.

Here, in a style, rather unconventional in an analytic text, I present three stories of the house. I take this approach because, as Michael Christie (another author in this issue) and I found as we did our field research work looking at Town Camp housing and its management, "wherever we were, we were told stories" (Campbell, 2012). The first purports to be a story that the house itself might tell; then a story from a well-meaning but harried public servant; and thirdly, from an Aboriginal Elder who is a member of a Housing Reference Group. While I assemble these stories I must remain vigilant so as not to fall into the trap of taking the position of the removed analyst, the 'judging observer' (Addelson, 2002, p.118), where I may attempt to provide some authoritative account of what everyone's perspective means when considered together.

What intrigues me as a researcher is that each story-telling figure appears to be talking about a different thing. They are not telling different stories of the "same" singular "thing" - the object 
that housing data seems to so strongly imply. At the start, this is what I assumed; that the house, was a house, was a house. They must be talking of the same thing! I assumed that the research process would help me understand the different perspectives on this same thing, and then my job would be to weave an account that was useful and truthful. I saw that as useful in the sense that, since I am positioned as a researcher, I would be able to show different parties how others thought, and thus enable the different people, each with interest in housing and its management, to understand the issue differently as a result of the research.

As it turns out, I am not sure that there is any 'same' thing. The house that I understand to be there is actually many different things: that which my imagined talkative Blue House thinks it is; that which Connie talks of and negotiates her way around; and an entity which is different again to Ronald. And by extension we can see that this process continues on: the houses are multiple. Other bureaucrats, other Aboriginal residents, other researchers (whether Aboriginal or not) are also seeing, thinking about and working with different houses, not different perspectives on the same ones. At this point I can see that some people would say that the presence of a physical structure means that we have an aggregation- a common starting point - which I am problematising (disaggregating) to find alternative ways of proceeding. I too thought this until I considered that in the real lives of the participants there is no agreed starting point - there is no fundamental agreement around what the house is and it is from this point that we need to proceed.

In the following sections I create three fictitious and partial (but also very real) stakeholder accounts of housing in Alice Springs Town Camps. What I am attempting to do by writing these accounts (and approaching writing this paper in this way) is to show that the various accounts of housing do not yet "hang together" in the way, for example, that atherosclerosis does in Annemarie Mol's (2002) accounts of a Dutch hospital. That is, by allowing it to be dealt with by various players, each in their own ways (that do not compromise the ability of others to deal with it in their own, different ways). It is this lack of hanging together that I wish to draw attention to, showing as it does that there is more work to be done to allow the different houses to come together in a way that the myriad stakeholders deem "good enough" for the purposes of going on together.

\section{The Blue House's story}

Hi there,

I'm a house on the Blue Gums Town Camp in Alice Springs. I'm a lot like the other houses in this camp, and indeed not dissimilar to lots of the houses on the other Town Camps. You could come and see me if you want, I'm painted blue and am the third house on the right as you come in. In the camp I'm known as the Blue house. I look a lot better than I used to; you see l've been refurbished. I'm over 20 years old, but with the refurbishment I almost feel brand new again! l've got three bedrooms, a nice verandah on one side and for the most part all of my parts are working- the shower, the heater, the windows and doors- all those things us houses like to have in working order. It isn't always like this; sometimes I have up to 15 people using me for shelter, and when this happens things can break down. Over the span of my life I've seen a lot of people pass through, and not all of these are what we call today 'tenants'; you see I am host to a steady stream of visitors, some of them from other Town Camps and some from out bush. In fact l've lost count of how many people have slept under my roof over the years. Today though, I'm vacant, I got no-one living in me...and you know what? It feels really, really strange. 
When I was built, and for the first fifteen years of my life, I was "managed" by my Housing Association, you see every Town Camp used to have their own Housing Association. In 2009 all that changed. Territory Housing took over and started "managing" me, and it was during this time that I came to understand that I was all of a sudden being thought about very differently to how I was when I was youngerand by a new set of people who never used to be interested in me (I put managing in those inverted commas because they all think they are managing me, yet really it is me managing all of them- they just don't realise it). The big difference I see is that those people in my Housing Association didn't just see me as bricks and mortar, walls and roof; they saw me as an integral part of their lives and the life of the community. Sure I was there to house people, to provide them with shade, safety and somewhere to call home, but they never saw me as just a physical thing; not as an individual thing that was distinct and separate from all the other ones or in fact to the people who slept and ate and talked in me.

My existence is proof of a number of things, of the battles that the old people fought to be recognised, of their right to a place in Alice Springs, not as fringe dwellers but real proper residents. I also help to connect people. I play a role in the stories that people tell about their lives and help to bring people together, across the years and the generations. The other thing too is that me and the Housing Association, we grew up together. Without me the Housing Association wouldn't exist; without me there would have been nothing for the people of this camp to organise around. In this sense I was more than a house. In the early days I was a symbol of success in the battles that those old people fought, getting title to the land on which I stand. I was also evidence that we belonged together - that I, and this land, belong to someone. Now however, I am a stake in an ongoing battle over who should decide my role and my fate. So I am more than just four walls and a roof, I have a role to play in keeping our community strong. I, along with the other houses, tell a story about who we are, where we came from and the battles we had to fight along the way.

Now though my new "managers" think of me differently, and it's a new way of thinking that I don't really understand, and for that matter not sure I like. You see for a start they don't acknowledge or appreciate my history. In fact I think many of them think of me as a problem to be sorted, not an asset to be used wisely. My new managers are seeking to sever my relationships with the other houses and the other people here. Of course even though this is what they seek, they cannot actually do it in the way that they imagine. They do not realise how determined the people of this camp are, or how powerful I am. 


\section{Ronald's story}

"Good morning everybody,

As you know l'm Ronald and I am convening this meeting of the Housing Reference Group (HRG) today; thanks everyone for coming. Today from Territory Housing we have me and Patricia, the Housing Support Officer.

Today we need to discuss a few things, including allocating a number of houses to families on the waiting list, as well as talking about the upcoming meeting where we need to renew the membership, which is something we have to do every year. So we'll talk a bit about how things have gone this year, who might want to stay on and who else from the camp might be interested in putting their hand up."

Today we are having another HRG meeting for Blue Gums Town Camp. This time we're holding it in the meeting room here at Territory Housing, because frankly it is just much easier for us to have it here. Normally the meetings for this group run pretty well (not like some of the others) but it is a constant battle to try to get them to remember what their role as a HRG member entails. I'm not sure that any of the members really understand the Terms of Reference, but it's too late for that now. I think people are still having trouble coming to terms with the idea that the houses are not their houses any more, and that they are here to provide advice, not make decisions. I know it must be hard, but that is the way things are now...

One of the things I don't understand is why people get so up in arms when we try to allocate a family in need to a particular house. Today we have one vacant house, number 5 Bilson Street, and I know that when I bring out the list that shows who is next in line for this house that people will not be happy with the particular family we think should go into this house. It's like all our talk about the criteria we have established to help make decisions about who gets a house - such as need - have just gone in one ear and out the other. Why can't they just see that this is a good outcome - a family in need getting a secure, refurbished house? Surely this is a good thing? I know they feel a bit disempowered; but know that we manage the houses now, not them. Sometimes it seems that they need reminding about this fact. 


\section{Connie's story}

My name is Connie and here I am at today's HRG meeting as one of the community members. It is being held here in the Territory Housing office in town rather than back at my town camp. Sometimes they do this, I think because they want to avoid humbug from other community members, and to keep the meetings short and airconditioned, but we think this is wrong. People should be able to see what is going on and be able to ask questions - people have issues that need to be addressed.

I feel really torn about being part of this HRG. You see I'm also a member of my Housing Association and in the past we used to make all the decisions about housing in my camp. Now l'm part of this HRG and our role is to provide advice to the Territory Housing about housing; but you know, they make it very clear that they are the ones who make the final decisions.

Now this man standing up, Ronald, he is a good man. He's from Territory Housing and I think he's trying to do a good job, but he just doesn't understand how important our houses are to us. Since we lost control over who gets to move into what house we have seen a whole new set of trouble. He knows we were not happy about how that SIHIP mob went about things, but he assured us that through the HRG we could make sure that once the houses were refurbished, we would be able to work together to make things better in my camp.

Today Ronald is showing us the list again, with all the people who need to be moved into a house. Some of them have special needs, like people on dialysis, but we can't just put anybody into any old house. We've got to make sure that the wrong people are not put into the houses, because we are the ones who suffer if they put the wrong people in the wrong house. And we are the ones that know that - not them. We know about all these people on the waiting list, and there is a lot of them we don't want to come into our camp, so they've got to listen to us. Ronald goes on and on about the criteria, but doesn't seem to appreciate that we have our own criteria. We also remember what Ronald said back when Territory Housing took over: the repairs and refurbishments were going to make things better - you know, reduce overcrowding and allow young families to start their own houses. Today he is here talking about the Blue house, and who he wants move into it. And he knows we don't want that next family on the list moving in there. You see we've been talking about who should move into the Blue House and old Rennie and Ningie have been very clear on who they think should move in. It's our job, us mob on the HRG, to keep our elders in the loop, and to make sure they are involved, even though they don't want to be on the HRG or go to the meetings. We have got to respect and support their knowledge and authority in this camp, keeping them strong keeps us all strong - and this whole place strong. I've lost count of the times I have tried to tell this to Ronald, but it seems like it is in one ear and out the other (I think they actually decide who goes into what house in Darwin, while trying to make it look like we are involved). Either way we battle along, what else can we do?

So the question I'm left with is: what does seeing the house that people interact with as different (rather than as different versions of the 'same' thing) allow us to do, particularly given our job here in the Research Hub of seeking to do work that 'makes a difference'? How can we understand and use productively an object of governance that is multiple? 
Seeing the Blue House as multiple allows me to ask different questions. Rather than "how do we find a way to agree on what the object is", we might instead think about how the Blue House positions us in relation to the philosophers fundamental question: "how should we live". The importance of this question emerges because we can see the participants, all of whom are good-hearted, struggling to find ways to go on together that are rewarding and productive. Multiplicity, if taken seriously, can reorient our collective work toward both the maintenance of difference (we are not seeking to create one authoritative account) while working together to produce just outcomes. It can do this because it focuses attention on the way truth claims are made, making visible the values embedded in knowledge practices. When these can be brought to the surface they can be worked with, creating the possibility for situated learning that can lead to new practices and new understanding.

\section{References}

Addelson, K. P. (1994). Moral passages: toward a collectivist moral theory. New York, NY: Routledge.

Addelson, K. P. (2002). The Emergence of the Fetus. In C.L. Mui \& J.S. Murphy (Eds.) Gender Struggles: Practical Approaches to Contemporary Feminism. (pp.118-136). Lanham, Maryland: Rowman \& Littlefield Publishers Inc.

Campbell, M. (2012, April). [Research field notes]. Unpublished raw data.

Mol, A. (2002). The Body Multiple: Ontology in Medical Practice, Durham \& London: Duke University Press.

Northern Territory National Emergency Response (2014, September 18). [Webpage]. Retrieved from http://www.aph.gov.au/Parliamentary_Business/Bills_Legislation/Bills_Search_Results/ Result?bld=r2850

Sullivan, P. (2011). The policy goal of normalisation, the National Indigenous Reform Agreement and Indigenous National Partnership Agreements. (Working Paper Number 76). Alice Springs, NT: Desert Knowledge CRC.

Tangentyere Council. (2014, 16 September). Welcome to Tangentyere Council [webpage]. Retrieved from http://www.tangentyere.org.au 